\title{
Anaerococcus tetradius
}

National Cancer Institute

\section{Source}

National Cancer Institute. Anaerococcus tetradius. NCI Thesaurus. Code C86876.

A species of anaerobic, Gram positive, cocci shaped bacteria assigned to the phylum Firmicutes. This bacteria is urease positive, indole and coagulase negative, ferments glucose and mannose but does not produces acid from raffinose. A. tetradius is a commensal organism of the mouth, skin, gastrointestinal and urinary tract and is considered an opportunistic pathogens in cases of immunosuppression or trauma. 